\title{
ASSOCIATIONS OF PEER GROUP AND SOCIAL MEDIA WITH HEALTHY EATING BEHAVIOR AMONG ADOLESCENTS
}

\author{
Frima Elda, Kusharisupeni \\ Center for Nutritional Studies, Faculty of Public Health, \\ Universitas Indonesia
}

\begin{abstract}
Background: Eating a balanced and varied diet and establishing healthy eating habits promotes young people's health, growth and intellectual development across the life- course. Bandura's Social Learning Theory posits that people learn from one another (e.g. how to eat), via observation, imitation, and modeling. This study aimed to estimate associations of peer group and social media with healthy eating behavior among adolescents.

Subjects and Method: This was a cross-sectional study conducted at several senior high schools in Jakarta. A sample of 400 high school students was selected for this study. The dependent variable was healthy eating behavior. The independent variables were peer group and exposure to positive social media. The data were collected by questionnaire and analyzed by a multiple logistic regression.

Results: Healthy eating behavior was positively associated with favorable eating habit of peer group $(\mathrm{OR}=2.86 ; 95 \% \mathrm{CI}=1.79$ to $4.10 ; \mathrm{p}=0.027)$ and exposure to positive social media $(\mathrm{OR}=3.45 ; 95 \% \mathrm{CI}=2.11$ to $5.98 ; \mathrm{p}=0.044)$.

Conclusion: Healthy eating behavior is positively associated with favorable eating habit of peer group and exposure to positive social media.
\end{abstract}

Keywords: eating behavior, healthy, peer group, social media, adolescent.

\section{Correspondence:}

Frima Elda. Center for Nutritional Studies, Faculty of Public Health, Universitas Indonesia. Email: frima_elda84@yahoo.com. Mobile: 085272802345 